\title{
The Study of fluviomarine rice field productivity and its effect on farmer's income in Mojowarno Village, Kaliori District, Rembang Regency
}

\author{
Azizatul Maghfiroh*, Sudrajat Sudrajat \\ Department of Environmental Geography, Faculty of Geography, Universitas Gadjah Mada, Indonesia
}

\begin{abstract}
Fluviomarine rice field is a type of agricultural land resulting from past marine activity processes with alluvium deposition material. This study specifically discusses the productivity of the rice field agricultural system by linking the physical components of the land based on the characteristics of geomorphological conditions (physiography, soil type, elevation contour, slope, and land use) with social interactions by local farmers. This study wants to analyze the productivity of the fluviomarine rice field farming system on agricultural income in Mojowarno village. This study uses 72 households data sample with the cluster random sampling method, which is based on the fluviomarine form cluster unit. The data analysis used a descriptive quantitative analysis. The results of this study are the fluviomarin rice fields farming system inMojowarno Village is a rainfed farming system with a planting frequency of only 2 times a year. Meanwhile, the average productivity of the land was only 5,307 tons /hectar, while the average income received by farmers was only Rp 5,879,631.00 /year. The regression statistical test results show that farmers' income is significantly influenced by land productivity. This study is expected to be used as a reference in preparing the development strategy for increasing farmer's income.
\end{abstract}

\section{Introduction}

Agriculture is one of the important sectors in an economic development. This occurs becauseagriculture functions as a food supply and job opportunities for residents in rural areas. In general, the agricultural systems developed in Indonesia are wetland systems, moorlands, yards, and plantation systems [5]. The agricultural system varies in Indonesia are greatly, both spatially and temporally. These variations of agricultural systems become very interesting part of the study of agricultural geography. One of the main concerns of agricultural geography on these variations in agricultural systems is study the causal relationship of a growing agricultural system in an area. The biophysical component and socio-demographic component will affect the agricultural system that is formed in an area. Therefore, understanding a complex agricultural system because it is formed from the interaction between physical and non-physical aspects, a geographic approach will be easy to understand.

One of the agricultural systems that very interesting in the study of geography is the fluviomarine rice fields agricultural system. This occurs because the fluviomarine rice fieldsare a type of agricultural land that located in the fluviomarine formations resulting from past marine activity processes with alluvium sediment material, which the population uses for agricultural activities. One of these types of land is located in the coastal area of the North Java Sea and it is behind the tidal flats with a rainfed lowland farming system. Utilization of fluviomarine lowland is the form of a rainfed agricultural system because it only relies on rainwater (rainfed rice). As the result, the agricultural system on fluviomarine fields is characterized by lower productivity than irrigated fields. In fact, rice plants only can plant once a year during the rainy season (September-December) [4].

The condition of the growing agricultural sector in fluviomarine rice fields will have an influence on the land productivity and farmers income. Productivity is a reflection of the quantity of production produced by agricultural land per unit area of land in a certain period [7]. Based on the Decree of the Minister of Agriculture No. 472 / Kpts / Rc.040 / 6/2018 concerning the Location of National Agricultural Areas which determine the national rice development area that Rembang is not a district that is a priority area for rice development [8]. The main problem in lowland rice cultivation in Kaliori District, Rembang Regency is low productivity. The average productivity of lowland rice has only reached 3.22 tonnes / ha. The physical characteristics of rice fields and the agricultural system implemented by farmerscause the level of productivity between rice fields to vary.

The low productivity of the fluviomarine rice fields cannot be separated from the characteristics of the fluviomarine plain land which can be seen from the type

\footnotetext{
${ }^{*}$ Corresponding author: azizatul.m@mail.ugm.ac.id
} 
of land that is developed, the availability of water sources, the ability of farmer's resources, and the availability of capital. Rice productivity in fluviomarine land cannot be separated from the influence of physical conditions; such as soil fertility conditions, types of commodities, the level of technology application, and socio-economic conditions of farmers [1]. The level of productivity of rice fields has an impact on the amount of income received by farmers. Therefore, research on the productivity of fluviomarine rice fields is very interesting. Basedon it, this study aims to analyze the fluviomarine rice fields agricultural system, to analyze theproduction and productivity of the fluviomarine rice fields, to analyze the agricultural income received by farmers, and to analyze the effect of fluviomarine rice fields productivity on agricultural income.

\section{Methods}

\subsection{Location}

This research was located in Mojowarno Village, which is one of the northern coastal zones of Java. Administratively, Mojowarno Village is included in the Kaliori District, Rembang Regency. Mojowarno Village consists of 3 hamlets, namely; Dukuh Samben, Dukuh Mojo, and Dukuh Cering. Based on the physical characteristics, there are two types of land resources in the Mojowarno area, namely; tidal flats and fluviomarin plains. The fluviomarine plain covers an area of 164.32 hectares and it used for lowland agricultural activities. Most of the residents of Mojowarno Village who work in agriculture are still of productive age, amounting to $64.41 \%$.

\subsection{Data}

Data collected in the form of primary data and secondary data. Primary data comes from interviews. Primary data collection is carried out directly through interviews with farmers using a structured questionnaire. In addition, indept interviews were conducted with the head of farmer groups and government officials in Mojowarno Village. Meanwhile, field observation activities are carried out by direct observation of agricultural production activities. Secondary data were collected from the village office, BPS and other agencies. Secondary data were collected in the form of administrative shapefile data for Mojowarno Village, map of terrain in Kaliori District at a scale of 1: 50,000, Land Map of Rembang Regency at a scale of 1: 80,000, google earth images, SRTM images, and geological shapefiles for Mojowarno Village. Secondary data in this study are to support research activities.

\subsection{Population and sample}

The population in the study were all heads of family (KK) farmers in Mojowarno Village andown rice fields. In 2020, there were 257 heads of farming families in Mojowarno Village, spread over 7 clusters of land units.
To determine the size of the sample size using the Slovin formula [9], as follows:

$$
\mathrm{n}=\frac{N}{N \cdot d^{2}+1}[9]
$$

Information:

$\mathrm{n}=$ the number of research samples

$d=$ tolerance limit for research sampling error

$\mathrm{N}=$ the number of the study population

The results of the calculation obtained a sample size of 72 households. Taking the number of samples from each cluster of fluviomarin landform units in a proportionate manner. Mathematically it can be formulated as follows:

$$
\text { Psi }=\frac{X i}{Y} X K
$$

Psi $=$ the number of sample proportions of rice land owners in landform units-i

$\mathrm{Xi}=$ the number of heads of household for owners of rice fields in landform units-i

$\mathrm{Y}=$ the number of head of household of rice fields (257 $\mathrm{KK}$ )

$\mathrm{K}=$ the number of research samples $(72 \mathrm{KK})$

The distribution of the number of samples from each cluster of fluviomarine landforms can beseen in Table 1 below.

Table 1. The number of samples of farmer households based on land unit clusters

\begin{tabular}{|c|c|c|}
\hline Number & $\begin{array}{c}\text { Land Unit } \\
\text { Code }\end{array}$ & $\begin{array}{c}\text { The number of } \\
\text { Samples (Head of } \\
\text { Family) }\end{array}$ \\
\hline 1 & A0112.N.w & 8 \\
\hline 2 & A013.F.w & 7 \\
\hline 3 & A013.N.w & 7 \\
\hline 4 & B03.R.w & 19 \\
\hline 5 & B03.U.pw & 8 \\
\hline 6 & B03.U.w & 15 \\
\hline 7 & B03.F.w & 8 \\
\hline \multicolumn{2}{|c|}{ Grand total } & 72 \\
\hline
\end{tabular}

Taking respondents from each cluster by random sampling. The random sampling methodprovides an equal chance of the population to be selected as a sample in a particular area [16].

\subsection{Data analysis}

The processing data of this research use several processing software including Microsoft Excel, ArcGIS, dan SPSS. Then, the method of data analysis using descriptive statistical analysis approaches, spatial analysis, and inferential statistical analysis. The data from interview with respondents about an agricultural systems, production and productivity of rice fields, and agricultural incomes are tabulating to be form of frequency tables, pie charts, or bar charts. Descriptive statistical analysis used to analyze the fluviomarine lowland agricultural system which was presented in the frequency distributiontable, while agricultural income was analyzed using the following equation:

$$
\begin{gathered}
N R=T R-T C \\
T R=P x Y \\
T C=T F C+T V C
\end{gathered}
$$

Information:

$\mathrm{NR}=$ Net Revenue (farmer's income)

$\mathrm{TR}=$ Total Revenue (total farmer revenue) 
$\mathrm{TC}=$ Total Cost (total cost of agricultural production)

$\mathrm{P}=$ price per unit of product

$\mathrm{Y}=$ total product

$\mathrm{TFC}=$ Total Fixed Cost

TVC $=$ Total Variable Cost

Analysis of farmers' income levels, from the results of using fluviomarine rice fields, the following mathematical equations are used:

$$
\text { Interval }=\frac{\text { maximum value }- \text { minimum value }}{\text { number of categories }}[14]
$$

Information:

Low category $=$ minimum value + interval

Moderate category $=$ low category value+interval

High category $=$ moderate category value+interval

Meanwhile, to analyze the productivity of fluviomarine rice fields, the following mathematical equation is used:

$$
\text { Productivity }=\frac{\text { total production (ton) }}{\text { land area }(\text { ha })}[12]
$$

To see the spatial distribution of productivity and agricultural income from fluviomarin rice fields, it was analyzed using a cluster approach [11]. Fluviomarine land units are differentiated based on land shape, soil type, lithology, elevation contours, and land use. The differentiated landformdata arranged in ArcMap layers according to administrative boundaries. The spatial distribution presented of the map of productivity and agricultural income in fluviomarine lowland with a scale of $1: 10,000$.

The presentation of the productivity and agricultural income map for rice fields are presented with an area symbol that represent a sample of rice fields in fluviomarine landform units. The symbol of area is divided into three different color gradations to distinguish agricultural productivity and income classes. Analysis of the pattern of productivity and agricultural income is compiled from an overlay of landform map with productivity levels and agicultural income of rice fields. Furthermore, an analysis of the pattern of agricultural productivity and income is carried out based on clusters of landform units associated with a sample of rice field area in each of these landform unit clusters.

Analysis of the effect of fluviomarine rice field productivity on agricultural income using simple linear regression analysis using SPSS software. Before using simple linear regression, the data were tested using the classical assumption test with normality test, linearity test, and heteroscedasticity test. Mathematically, the simple linear regression equation model is used:

$$
Y=\beta 0+\beta X+\varepsilon
$$

Information :

$\mathrm{Y}=$ dependent variable (farmer income)

$\mathrm{X}=$ independent variable (lowland productivity)

$\beta 0=$ constant

$\beta=$ regression constant $/$ independent variable coefficient

$\varepsilon=$ error

To determine the strength of the relationship between variables analyzed using the correlation coefficient. The type of correlation used the Pearson product moment (r) [13], as follows:

Information :

$$
\mathrm{r}_{\mathrm{xy}}=\frac{n \sum X Y Y i-\left(\sum X i\right)\left(\sum Y i\right)}{\left[n \sum X i^{2}-\left(\sum X i^{2}\right)\right]\left[n \sum Y i^{2}-\left(\sum Y i^{2}\right)\right]}[13]
$$

$\mathrm{Y}=$ dependent variable (farmer income)

$\mathrm{X}=$ independent variable (lowland productivity)

Meanwhile, to determine the magnitude of the influence of the independent variables (rice field productivity) on the dependent variable (farmer income), it is analyzed using the following mathematical problems:

Information:

$$
\mathrm{Kd}=r^{2} x 100 \% \quad[13]
$$

$\mathrm{Kd}=$ determination coefficient

$\mathrm{r}=$ correlation coefficient

If the determinant coefficient value is close to $100 \%$, the independent variable (productivity) is able to explain all the information needed to predict the dependent variable (income). The results of linear regression analysis and correlation were analyzed descriptively quantitatively. A more indepth analysis is supported by information from the farmer groups and the village information management officers. This information obtained during the data collection process, especially secondary data that available at the village office.

\section{Result and discussions}

\subsection{Characteristic of farmer households of fluviomarine rice field agriculture}

In this study, the characteristics of farmers were analyzed by demographic and socio- economic characteristics. Demographic characteristics include age, sex, number of household members, and number of working household members, while socio-economic characteristics include factors of education, length of farming, and land area. Respondents in this study are farmers who carry out agricultural activities, especially fluviomarine rice fields. The farmer respondents can act as private landowners, tenant farmers, or sharecroppers with a profit-sharing system. The farmers carry out farming activities in fluviomarine fields from generation to generation in addition to carrying out farming activities in ponds.

According of Table 2 it is known that the average age of the farmers is $>35$ years. This phenomenon shows that currently the agricultural sector is less attractive to young workers. Meanwhile, the level of education is mostly still low $(87.5 \%$ have primary school education/equivalent). The farming experience ranges from 32 years, while the average rice field is 0.29 hectares. The results of this study illustrate that agricultural activities are carried out by farmers who are old with low education and narrow land ownership. Based on the results of interviews with the village head, the large of old age farmer in this village is due to the lack of regeneration of young farmers. The farmer's childern prefer to continue living outside the city either continue their education or work as factory workers. So that no one continues to work on the rice fields. 
Table 2. Demographic and Sosio-Economic Characteristic of Farmer's Fluviomarine Rice Fields in Mojowarno Village at 2020.

\begin{tabular}{|c|c|c|}
\hline $\begin{array}{l}\text { Charac- } \\
\text { teristic }\end{array}$ & Description & Information \\
\hline \multirow{4}{*}{$\begin{array}{l}\text { Demographi } \\
\text { c }\end{array}$} & $\begin{array}{l}\text { Average age of } \\
\text { respondents (years) }\end{array}$ & 55 \\
\hline & Sex & Man \\
\hline & $\begin{array}{l}\text { The average number } \\
\text { of household } \\
\text { members (people) }\end{array}$ & 3 \\
\hline & $\begin{array}{l}\text { The average } \\
\text { number of working } \\
\text { household members } \\
\text { (people) }\end{array}$ & 2 \\
\hline \multirow{6}{*}{$\begin{array}{l}\text { Sosio- } \\
\text { Economic }\end{array}$} & $\begin{array}{l}\text { Respondent's } \\
\text { education (people): }\end{array}$ & \\
\hline & a. No school & 1 \\
\hline & $\begin{array}{l}\text { b. Elementary } \\
\text { school }\end{array}$ & 63 \\
\hline & $\begin{array}{l}\text { c. Junior High } \\
\text { School }\end{array}$ & 7 \\
\hline & $\begin{array}{l}\text { d. Senior High } \\
\text { School }\end{array}$ & 0 \\
\hline & e. Bachelor & 1 \\
\hline \multirow{2}{*}{$\begin{array}{l}\text { Sosio- } \\
\text { Economic }\end{array}$} & $\begin{array}{l}\text { The average time of } \\
\text { farming (years) }\end{array}$ & 32 \\
\hline & $\begin{array}{l}\text { The average area of } \\
\text { rice land (ha) }\end{array}$ & 0.29 \\
\hline
\end{tabular}

\subsection{Agricultural system in fluviomarine rice field}

The rice field system that developed in Mojowarno village is dry rice fields or called rainfed lowland agriculture. This is because the rice fields in the research location have limited water sources and only depend on the availability of rainwater. The variations in the components of the agricultural system in a region can be grouped into five components, namely; land processing techniques, planting frequency, types of planting commodities, planting season, and cropping patterns [3]. The results showed that the farmers in the location research were using tractors to cultivate rice fields. Farmers think that using tractors to cultivate rice fields will speed up their work, even though they need more capital.The frequency of planting in fluviomarine rice fields averaged 2 times a year with the main rice crop commodity (Table 3).

Table 3.Frequency of planting on fluviomarine rice fields in Mojowarno Village.

\begin{tabular}{|c|c|c|}
\hline $\begin{array}{c}\text { MT1 } \\
\text { (Nov-Feb) }\end{array}$ & $\begin{array}{c}\text { MT2 } \\
\text { (Mar-Jun) }\end{array}$ & $\begin{array}{c}\text { MT3 } \\
\text { (Jul-Oct) }\end{array}$ \\
\hline Rice & Rice & Fallow \\
\hline
\end{tabular}

In Table 3, it can be seen that the planting season of rice (MT) in Mojowarno Village is divided into 3 times a year, namely; MT1 (the beginning of the rainy season in early November), MT 2 (the season before the dry season in mid-March-late June), and MT3 (the dry season at the beginning of July - the end of October).
The results of the study found that $78 \%$ of farmers in Mojowarno Village applied a rice-fallow cropping pattern. This happens because the water source relies on only rain water. As a result, the time for planting rice is highly dependent on the arrival of the rainy season which on average falls in November-Junewhile the dry season starts in July until October. The difference in conditions between theseseasons allows the occurrence of gaps in agricultural production between seasons [10]. An effective, efficient, sustainable, and high-productive agricultural system can be ralized by utilizing land based on the ability and sustainability of rice fields as well as the characteristics of the agricultural system carried out by farmers.

\subsection{Fluviomarine rice field based on land cluster}

The topography of the fluviomarine plain and alluvial plain is sloping to flat. Alluvial plainsformed from river sediment are generally found in the central part of Mojowarno Village which is associated with the river flow in the middle of the village, while the fluviomarine plains generally dominate all of the rice fields. Geological conditions of rice fields generallyconsist of past fluviomarin deposits in the form of clay and sand deposits. Rice fields like this are generally found in flat areas with slopes of $0-2 \%$ and in limited areas are found in $2-6 \%$ very sloping areas and $6-13 \%$ sloping areas. The total area of rice fields in Mojowarno Village is 138.47 ha. The rice fields are divided into 7 clusters of rice fields based on the characteristics of the terrain (physiography, slope, and land use) (Table 4 and Figure 1).

Table 4. Characteristics of fluviomarin rice fields in Mojowarno Village

\begin{tabular}{|c|c|c|c|c|}
\hline $\begin{array}{l}\text { Clus } \\
\text {-ter }\end{array}$ & Code & Physiography & Slope & $\begin{array}{c}\text { Land } \\
\text { Use }\end{array}$ \\
\hline 1 & $\begin{array}{l}\text { A0112.N. } \\
\text { W }\end{array}$ & $\begin{array}{l}\text { Curved } \\
\text { floodplain in } \\
\text { meander }\end{array}$ & $\begin{array}{l}\text { little flat } \\
(0-2 \%)\end{array}$ & $\begin{array}{l}\text { Rice } \\
\text { field }\end{array}$ \\
\hline 2 & $\begin{array}{l}\text { A013.F. } \\
\mathrm{w}\end{array}$ & $\begin{array}{l}\text { Alluvial } \\
\text { terraced plain }\end{array}$ & $\begin{array}{l}\text { Flat }(0- \\
2 \%)\end{array}$ & $\begin{array}{l}\text { Rice } \\
\text { field }\end{array}$ \\
\hline 3 & $\begin{array}{l}\text { A013.N. } \\
\text { w }\end{array}$ & $\begin{array}{l}\text { Alluvial } \\
\text { terraced plain }\end{array}$ & $\begin{array}{l}\text { little flat } \\
(0-2 \%)\end{array}$ & $\begin{array}{l}\text { Rice } \\
\text { field }\end{array}$ \\
\hline 4 & B03.R.w & $\begin{array}{l}\text { The northern } \\
\text { coast of Java } \\
\text { fluviomarine } \\
\text { plain }\end{array}$ & $\begin{array}{l}\text { Sloping } \\
\text { slope } \\
(6-13 \%)\end{array}$ & $\begin{array}{l}\text { Rice } \\
\text { field }\end{array}$ \\
\hline 5 & $\begin{array}{l}\text { B03.U.p } \\
\text { W }\end{array}$ & $\begin{array}{l}\text { The northern } \\
\text { coast of Java } \\
\text { fluviomarine } \\
\text { plain }\end{array}$ & $\begin{array}{l}\text { very } \\
\text { gentle } \\
\text { slope } \\
(2-6 \%)\end{array}$ & $\begin{array}{l}\text { Settle } \\
\text { ment } \\
\text { and } \\
\text { rice } \\
\text { field }\end{array}$ \\
\hline 6 & B03.U.w & $\begin{array}{l}\text { The northern } \\
\text { coast of Java }\end{array}$ & $\begin{array}{l}\text { very } \\
\text { gentle }\end{array}$ & $\begin{array}{l}\text { Rice } \\
\text { field }\end{array}$ \\
\hline
\end{tabular}




\begin{tabular}{|c|l|l|l|l|}
\hline & & $\begin{array}{l}\text { fluviomarine } \\
\text { plain }\end{array}$ & $\begin{array}{l}\text { slope } \\
(2-6 \%)\end{array}$ & \\
\hline 7 & B03.F.w & $\begin{array}{l}\text { The northern } \\
\text { coast of Java } \\
\text { fluviomarine } \\
\text { plain }\end{array}$ & $\begin{array}{l}\text { Flat (0- } \\
2 \%)\end{array}$ & $\begin{array}{l}\text { Rice } \\
\text { field }\end{array}$ \\
& & & \\
\hline
\end{tabular}

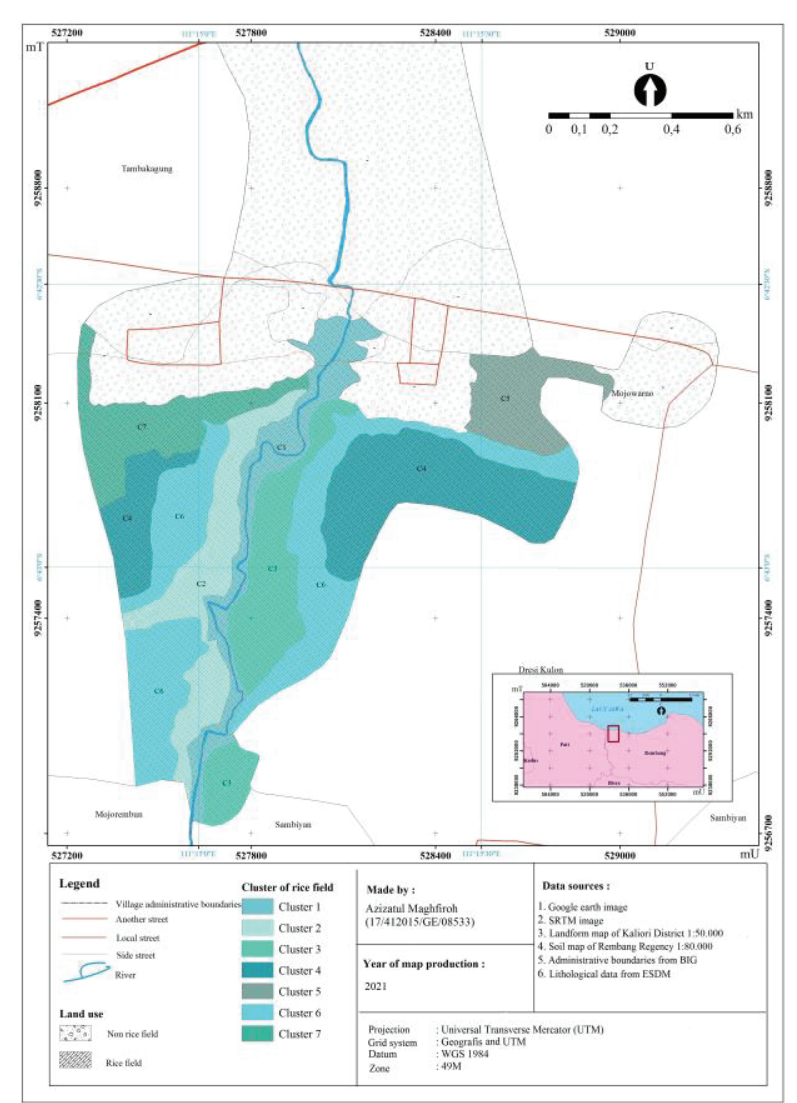

Fig. 1. Map of fluviomarine rice field distribution according to clusters in Mojowarno Village.

All rice fields in cluster 1 are often flooded when there is excess water in the rainy season. This is because the location of rice fields is on a meandering curve so that it will experience excess water in the rainy season. The commodity cultivated in this rice fields is dominated by rice plants because of its proximity to the river flow so that the water source is able to meet the planting process. Some of the rice fields in the cluster 2 and cluster 3 have the potential to be flooded when the water supply is abundant in the rainy season, especially in the rice fields around the river meanders. The main commodity cultivated in the first and second planting seasons is rice plants, while in the third planting season is crops like a mung beans and corn are planted. The rice fields in cluster 4 have no potential for flooding due to its sloping topography. In addition, the distance from water source to rice fields is relatively far, which affects water control efforts, especially in the dry season.

Meanwhile, some rice fields in cluster 5 have the potential to be flooded when the water supply is abundant in the rainy season. The ability of farmers to plant until 2 times a year is supported by efforts to control water during the planting process, especially in the dry season. The sloping topography of cluster 6 rice fields causes the appearance of rice fields to have terraced bund with no potential for flooding. In some land, the bunds of the rice fields are used to grow crops such as cassava and corn. The location of rice fields in cluster 7 which is far away from the main river that minimizes the potential for flooding. Meanwhile, the location of this land is too close to residential areas, causes an intensive land management. The main commodity cultivated in the first and second planting season is rice, while in the third planting season is crops with mung beans or uncultivated.

\subsection{Productivity and production of fluviomarine rice field}

Rice field productivity is a comparison of production yields with land area in a certain time period. The results of the study found that the fluviomarine rice fields in Mojowarno Villagewere able to produce 1.9-5.5 tons of milled dry unhulled rice per year. In this study, the productivity of rice fields is grouped into 3 (three), namely low productivity ranging from 4.36-4.92 tonnes / ha, moderate productivity ranging from 4.93-5.49 tonnes / ha, and high productivity ranging from 5.50 tonnes / ha. -6.03 ton / ha. More clearly the production of planting area and productivity of fluviomarine rice fields can be seen in Figure 2 below.

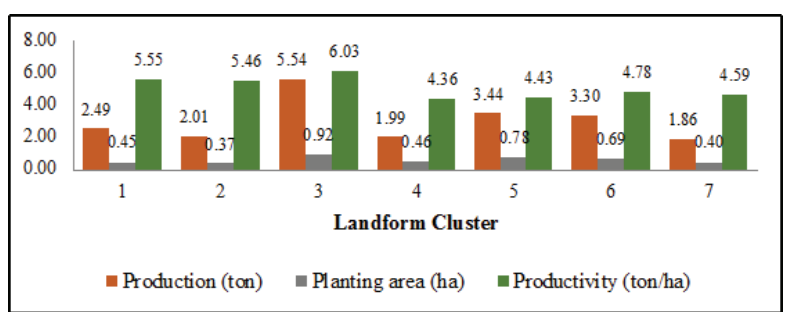

Fig. 2. Production, planted area, and productivity of fluviomarine rice fieldsaccording to land clusters.

In Figure 3, it can be seen that the distribution of rice field productivity in the village according to the cluster is dominated by low productivity levels. Low productivity is in 4 (four) clusters, namely cluster 4, cluster 5 , cluster 6 , and cluster 7 with a total land area of 79.95 ha or about $64.32 \%$. For rice fields with high productivity are found in cluster 3 and cluster 1 with an average productivity value of 5.55-6.03 tonnes / ha, while rice fields with moderate productivity are found in cluster 2 with an average productivity of 5.46 tonnes. /Ha.Meanwhile, it can be seen that the productivity of fluviomarin rice fields in Mojowarno Village is on average 5.03 tonnes / ha. The results of this study are in line with the findings of Jonharnas \& Sitindaon (2017) in Deli Serdang Regency, which is 5.44 tonnes / ha.

This study also found that the spatial pattern of productivity distribution of rice fields showed a grouping tendency, based on the similarity of physiographic types. This can be seen in lowproductivity rice fields clustered in cluster 4 , cluster 5 , cluster 6 , and cluster 7 with a slope between $0-2 \mathrm{~m}$ and flat topography. The low average productivity ahead of the dry season isdue to the fact that the cluster only has limited water sources, so 
agricultural land often becomes dry. In addition, it is also caused by the formation of rice fields which is influenced by the formation of the origin of the past marine process which leaves a salt content (salinity). This condition will ultimately affect the ability of plants to grow and develop in producing agricultural production. More clearly, the distribution of rice field productivity can be seen in Figure 3 below.

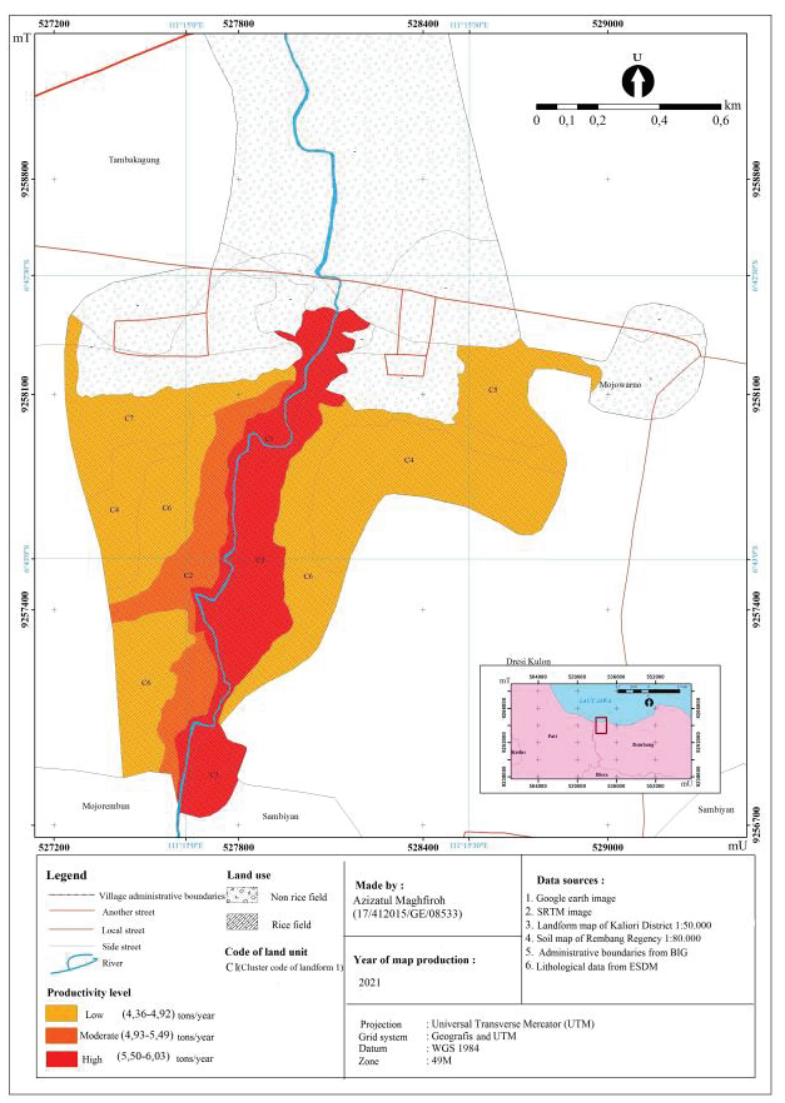

Fig. 3. Distribution map of rice field productivity according to land cluster in MojowarnoVillage, Kaliori District, Rembang Regency

For the medium level of productivity, the cluster 2 rice fields are located west of the main river with a flat slope $(0-2 \%)$. Meanwhile, high productivity levels are clustered in cluster 1 and cluster 3 rice fields, which are located east of the main river. The rice fields to the west of the river have a lower slope than the rice fields to the east of the river with flat to slightlyflat slopes $(0-2 \%)$. This condition causes the rice fields to the west of the river when the rainy season has the potential to be flooded. In fact, there are several rice fields that are submerged in water so that the commodity crops are damaged which has the potential to reduce the areaof harvested land and its production. As a result, it has an impact on the low level of productivity of rice fields to the west of the river compared to the east. Even though cluster1,cluster 2 , and cluster 3 have the opportunity to always be flooded during the rainy season, during the dry season they benefit because they can use river water to irrigate the land of ricefields easily. Another factor that causes low rice production on the west side of the river is due to the process of washing the soil during floods and high salt deposits that are depositedin the soil. These two phenomena ultimately lead to a decrease in soil fertility. Based on this, it is quite logical that the rice production on the west side of the river is lower than that in theeast side of the river.

\subsection{Fluviomarine rice field agricultural income}

Analysis of income received by farmers from the use of fluviomarin rice fields in this study was used to analyze the amount of profits received by farmers in one year. Factors that affectthe size of farmers' income include the frequency of farming activities in one year, the levelof production or productivity of rice fields, and the prevailing price of agricultural commodities. The income received by farmers is determined by the amount of production generated from farming and the amount of costs incurred during cultivating agricultural activities. The results of the study found that the average income of the fluviomarin rice field farmers in Mojowarno Village was still low, namely Rp. 5,879,631.00 / year with an average of 0.29 hectares of rice fields. The distribution of farmer income from farming products in Mojowarno Village can be seen in Figure $\mathbf{4}$ below.

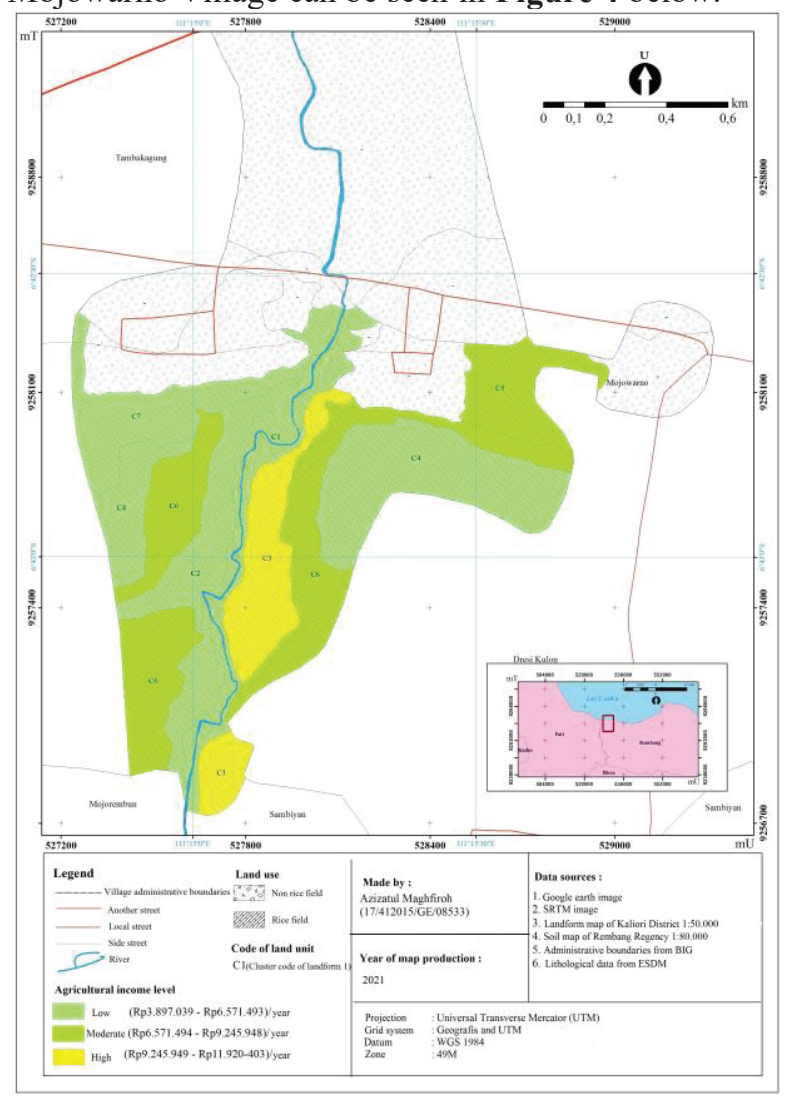

Fig. 4. Distribution map of agricultural revenue according to the land cluster in Mojowarno Village, Kaliori District, Rembang Regency

In Figure 4, it can be seen that the distribution of fluviomarine rice field farmer's income levels according to clusters is quite varied. High income farmers are found in cluster 3 , farmers classified as medium income are found in cluster 4 and cluster 5, while farmers classified as low income are found in cluster 1 , cluster 2 , cluster 6 , and cluster 7 . Variations in the amount of income received by land farmers fluviomarin fields are caused by wide variations and production. In cluster 3 , 
the farmers cultivate an average rice field of 0.4258 ha with an average production of 5.535 tons. In cluster 4 and cluster 5 the average land areacontrolled is 0.325 with an average production of 2.715 tons. Meanwhile, in cluster 1 , cluster 2 , cluster 6 , and cluster 7 , the average area of rice fields controlled by farmers was only 0.2444 ha with an average production of 2.415 tonnes. This high income received by farmersin each cluster area is closely related to the area and production of land. The results of the study are in line with the results of research by Kusnadi, et al., (2011) which stated that the more rice fields cultivated for agricultural activities the higher the production and the higherthe farmer's income and vice versa [6].

\subsection{Effect of fluviomarine rice field productivity on farmer's income}

High land productivity will reflect high yields of land and will ultimately result in high income. Based on this, to determine the magnitude of the influence of rice field productivity on farmers' income, a linear regression statistical test was carried out. Simple linear regression statistical tests can be analyzed by performing the classical assumption test first which includes the assumptions of normality, linearity, and heteroscedosticity. In Figure 5, the graph of the relationship between productivity variables and farmer income variables is linear.

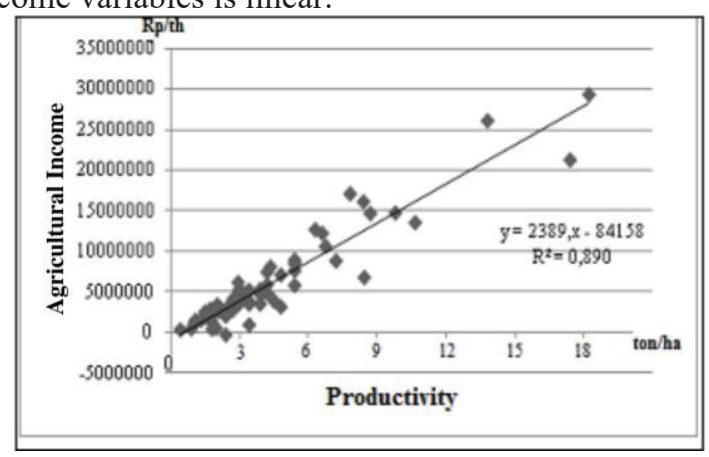

Fig. 5. Linearitas graph

The results of the linear regression test showed that the t-count value was 23.807 more than the $t$-table 1.9944 so that it can be seen that the productivity variable of rice fields has an effect on the variable of farmer's income. Meanwhile, the significance value of 0.000 less than 0.05 at the $95 \%$ confidence level indicates that the regression model can be used to explain significantly the effect of the level of productivity on farmers' income. The constantvalue is $841,580,634$ and the regression coefficient value is $2,389,387$ so that the regression equation is $\mathrm{Y}=$ $841,580,634+2,389,387 X$. This shows that every $1 \%$ increase in the productivity of rice fields, the farmer's income will increase by 2,389,387, assuming other factors are constant. The regression coefficient is positive, so it can be said that the direction of the influence of the rice field productivity variable with the farmer income variable is positive. Meanwhile, seen from the value of $\mathrm{R}$ Square (coefficient of determination), the value is 0.890 . The $\mathrm{R}$ square value of 0.890 means that the land productivity variable is able to have an effect on farmers' income by $89 \%$, while the magnitude of other variables not examined in this study has an effect of $11 \%$. The results of this study are in line with the results of research by Baizhurah (2014) in East Seunagan, Nagan Raya Regency, which found that farmers' income was significantly affected by the $\mathrm{R}$ Square value of 0.990 [2]

\section{Conclusion}

The fluviomarin rice field farming system in Mojowarno Village is a rainfed farming systemwith a planting frequency of only 2 (two) times a year so that the dominant cropping pattern is rice-rice-fallow. On average, the farmers have a rice field area of 0.29 ha with productionreaching 1,856-5,535 tons of unhulled rice / year. Meanwhile, the average productivity of the land was only 5,307 tons / ha, while the average income

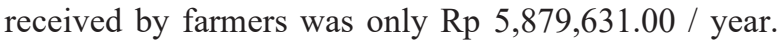
The regression statistical test results show that farmers' income is significantly influenced by land productivity. The effect of land productivity on farmer income is positive. This means that the increase in the productivity of fluviomarine rice fields will be followed by an increase in the income received by farmers.

On this occasion the authors would like to thank the UGM Publisher and Publication Board (PBB) for providing RTA 2021 Grant funds, so that the authors can attend the ICST 2021 seminar and complete the thesis. And also really appreciate reviewers for suggestions to make this article better. Without all of these supports, this research would not be successful. Hopefully, this article will be useful for the future.

\section{References}

1 S. Arsyad, Konservasi Tanah dan Air (2 ${ }^{\text {nd }}$ ed.) (IPB Press, Bogor, 2018)

2 N. Baizhurah, Analisis Pengaruh Produksi Padi Sawah Terhadap Pendapatan Masyarakat di Kecamatan Seunagan Timur Kabupaten Nagan Raya. Skripsi (Universitas Teuku Umar, Aceh, 2014)

3 L. Fresco, Cassava in Shifting Cultivation: A Systems Approach to Agricultural Technology Development in Africa (Development Oriented Research in Agriculture, Royal Tropical Institute, Netherlands, 1986)

4 J. H. Jonharnas,. S. H. Sitindaon, Jurnal Agroteknologi, 7(2), 15-20 (2017)

5 E. Kusmiadi, Pengertian dan Sejarah Perkembangan Pertanian. In Pengantar Ilmu Pertanian (pp. 1-28) (2014)

6 N. Kusnadi, N. Tinaprilla, S. H. Susilowati, A. Purwoto, Jurnal Agro Ekonomi, 1(29), 25-48 (2011)

7 S. Mangkuprawira, Manajemen Mutu Sumberdaya Manusia (Ghalia Indonesia, Bogor, 2007)

8 Badan Penelitian dan Pengembangan Pertanian. Sentra Produksi. Accessed date $22 \quad$ September 2020 from: 
http://inaagrimap.litbang.pertanian.go.id/index. php/sentraproduksi/tanaman- pangan/padi. (2018)

9 Ridwan. Metode dan Teknik Penyusunan Tesis. (CV Alfa Beta, Bandung, 2005)

10 Satoto, Y. Widyastuti, U. Susanto, M. J. Mejaya, IPTEK Tanaman Pangan, 8(2) (2013)

11 Scott,.Warmerdam. Spatial Statistics for Public Health and Safety (ESRI, San Diego, 2006)

12 E. Silamat, Yuwana, M. Z. Yuliarso, Agrisep, 14(2), 197-215 (2014)

13 Sugiyono. Metode Penelitian Kuantitatif Kualitatif dan R\&D (Alfabeta, Bandung, 2012)

14 J. Supranto, Statistik Teori dan Aplikasi (Erlangga, Jakarta, 2000)

15 S. H. Susilowati, Forum Penelitian Agro Ekonomi, 34(1), 35-55 (2016)

16 Triyono. Teknik Sampling Dalam Penelitian Sosial. Lokakarya Penelitian Sosial Fakultas Adab IAIN Suka Yogyakarta, XI(March), 2-9 (2018) 